\title{
Observations on a presumed bilateral gynandromorph Black Redstart Phoenicurus ochruros paired with a male
}

\author{
Observationer av en förmodat bilateral gynomorf \\ svart rödstjärt Phoenicurus ochrurus \\ i par med en hanne
}

Nicolas Martinez

Heuschluge 8,4118 Rodersdorf, Switzerland | nicolas.martinez44@yahoo.de

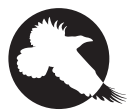

A SUPPOSED bilateral gynandromorph Black Redstart Phoenicurus ochruros in northwestern Switzerland formed a pair with a phenotypically classical male, but apparently was not breeding. The bird was documented before and after moult, when all replaced feathers were again of the same sex type. It was also recorded singing, the song being typical for the species. This is the second recorded case of a bilateral gynandromorph Black Redstart, one of only a handful cases where wild bilateral gynandromorph birds have been observed throughout the breeding season, and the first unequivocal documentation of a presumed bilateral gynandromorph bird forming a stable pair with a typical male.

Keywords: gynandromorphism | chimera | sex | moult | passerine

\section{Introduction}

In this article, I document prolonged observations of a supposed bilateral gynandromorph Black Redstart Phoenicurus ochruros in Rodersdorf, Switzerland. The bird formed a pair with a phenotypical classical male, and was documented before and after moult and recorded when singing.

A gynandromorph is defined as an organism displaying a combination of male and female character- 
istics. This very rare condition may be bilateral, with one half of the organism showing male characteristics and the other half showing female characteristics (Kumerloeve 1954). Such gynandromorph individuals are sometimes called "half-siders". Due to their striking appearance, gynandromorph birds have been documented already in the $19^{\text {th }}$ century, with early overviews in Kumerloeve (1954) and Patten (1993). Since then, several additional records have been published (e.g. DaCosta et al. 2007, Peer and Motz 2014, Jones \& Bartlett 2017).

Gynandromorphs have been found in many different bird families and species. Unsurprisingly, most-if not all-records come from species with plumage-related sex differences. Most documented wild gynandromorphs refer to museum specimens, to birds having been caught, or to brief observations. Thus, the observation of the present gynandromorph is of interest: It concerns one of very few documented gynandromorphs being apparently paired and the observations cover a relatively long time span during which the bird could be documented before and after moult and was recorded singing.

\section{Observations and behaviour}

In late March 2019 a supposed Black Redstart pair occupied a territory in an area of houses adjacent to an orchard in Rodersdorf, northwestern Switzerland $\left(47^{\circ} 29^{\prime} 00.3^{\prime \prime} \mathrm{N} 7^{\circ} 27^{\prime} 21.8^{\prime \prime} \mathrm{E}\right)$. The first time I saw the bird was on 31 March and it became apparent that it was not a normal female. During the following days, I was able to observe it on at least 27 days until 14 September 2019, the day when it was last recorded (see Appendix 1).

The bird seemed to be paired with a normal adult $\left(3^{\text {rd }}\right.$ calendar year or older; $\left.3 \mathrm{CY}+\right)$ male. In April, May, and June both birds were almost exclusively seen together. Later in June and July the gynandromorph was observed alone, too (see Appendix 1). However, both birds were regularly observed together without aggressive behaviour until at least 28 July 2019 , the date after which only the gynandromorph remained in the territory. During the last two observations, on 5 and 14 September 2019, the gynandromorph had a visible injury, ulcer or abscess on the throat (see Figure 1).

When being together, the birds used to move together across their territory in search of insects and were quietly sitting next to each other during breaks. When sitting on rooftops, trees, and other structures they often did so in close proximity of each other (see Figure 2 and video at https://www.youtube.com/watch?v=ANBeyp4izOM). This was done apparently without any aggression, whereas they behaved aggressively against an intraspecific intruder to their territory and chased it away together on 13 April. The male showed normal singing behaviour of a territory owner from the end of March onwards. The gynandromorph was briefly heard singing for the first time on 13 April 2019 and later in May and June it was singing more regularly (see below for a description of the song). When one of the two birds was singing, the other was sometimes quietly sitting at a few meters' distance. I never saw either of the birds carrying nesting material, nor did I see them mating.

\section{Description of the bird}

\section{PLUMAGE}

The right part of the bird was that of a typical adult male bird being at least in its third-calendar year with the typical blackish-grey plumage except for the large white wing patch and the reddish tail including rump, uppertail and undertail coverts (see Figure 1 and video at https://youtu.be/x2KLmd23 B2Y). On close inspection of photographs, I did not find any sign of browner feathers as an indication for female sex. The left part of the bird was much more variable, with mainly a female appearance, i.e. a drab grey-brown ground colour (Figure 1). Yet, there were clearly some male plumage parts, too. This was most obvious on the upper breast and some all-black parts of the head. There was a mixture of grey-brown (supposed female) as well as more pure grey (supposed male) feathers on the back. Finally, the left wing presented a mixture of male and female type feathers: The outer greater coverts, the longest tertiary and the secondaries 4-7 (numbered ascendingly, i.e. primary 1 is outermost) were of adult male type, the remaining secondaries, tertiaries and greater coverts were of female type. Black Redstarts undergo a complete post-breeding moult in July and August (Nicolai et al. 1996). After moult, all replaced feathers were again of the same sex type as before moult, which is well visible in Figure 1, especially for the secondaries. 


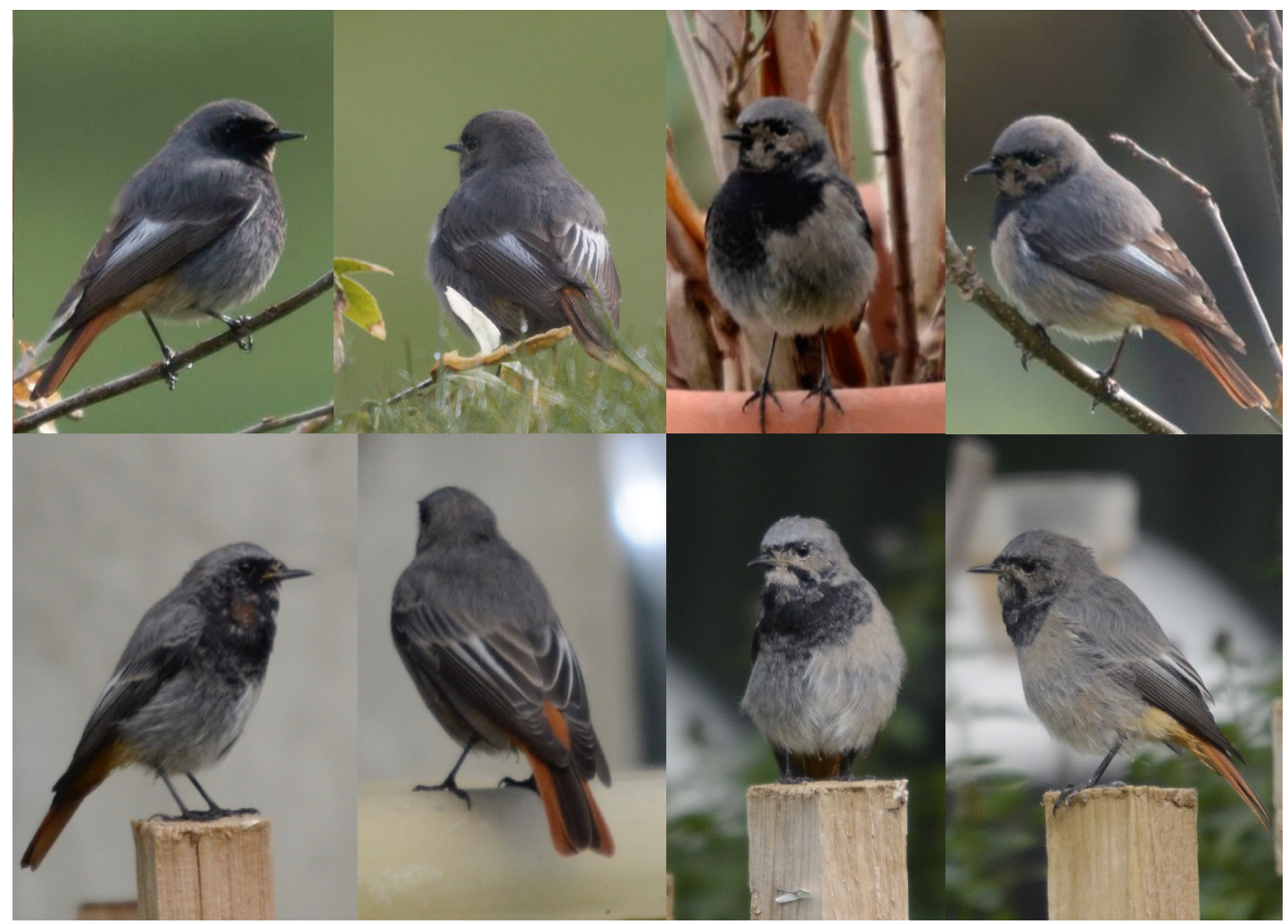

FIGURE 1. Different views of the supposed gynandromorph Black Redstart Phoenicurus ochruros in April 2019 (upper series) and September 2019 (lower series, after post-breeding moult).

- Den förmodat bilaterala gynandromorfa svarta rödstjärten Phoenicurus ochrurus i april 2019 (övre raden) och september 2019 (nedre raden, efter komplett sommarruggning).

\section{SONG}

The song was that of a normal Black Redstart, starting with some whistles, followed by a short pause and the species-specific scratchy notes, just before ending with some whistles again. Just as in normal male Black Redstarts, some of the strophes were incomplete. Duration of complete strophes was roughly 4 seconds, again as in normal males (Martinez et al. 2019). Recordings can be found at https://www.xeno-canto.org/471015 and https://www.xeno-canto.org/471014.

\section{Discussion}

At first glance, the presumed bilateral gynandromorph could be considered being a male with a partially suspended moult, since most juvenile males have a plumage nearly identical to females. However, second- aries and primaries only develop white feather margins in Black Redstart males after the first complete moult during their first summer (Nicolai et al. 1996). Thus, the bird was $3 \mathrm{CY}+$, and retained juvenile feathers at this age are very unlikely. Additionally, female-type feathers were again of female type after moult in summer 2019.

To my knowledge, the observation is one of only very few, where a gynandromorph was documented before and after moult, heard as well as recorded singing, and showing breeding behaviour. Previous records of obviously paired or breeding birds that I am aware of, are a Northern Cardinal Cardinalis cardinalis apparently paired with a female of the same species (Bohlen 2006), an Eastern Towhee Pipilo erythrophthalmus observed singing and feeding young (Brenner et al. 2019) and the only other documented case of a suspected gynandromorph Black Redstart, which was paired with a 


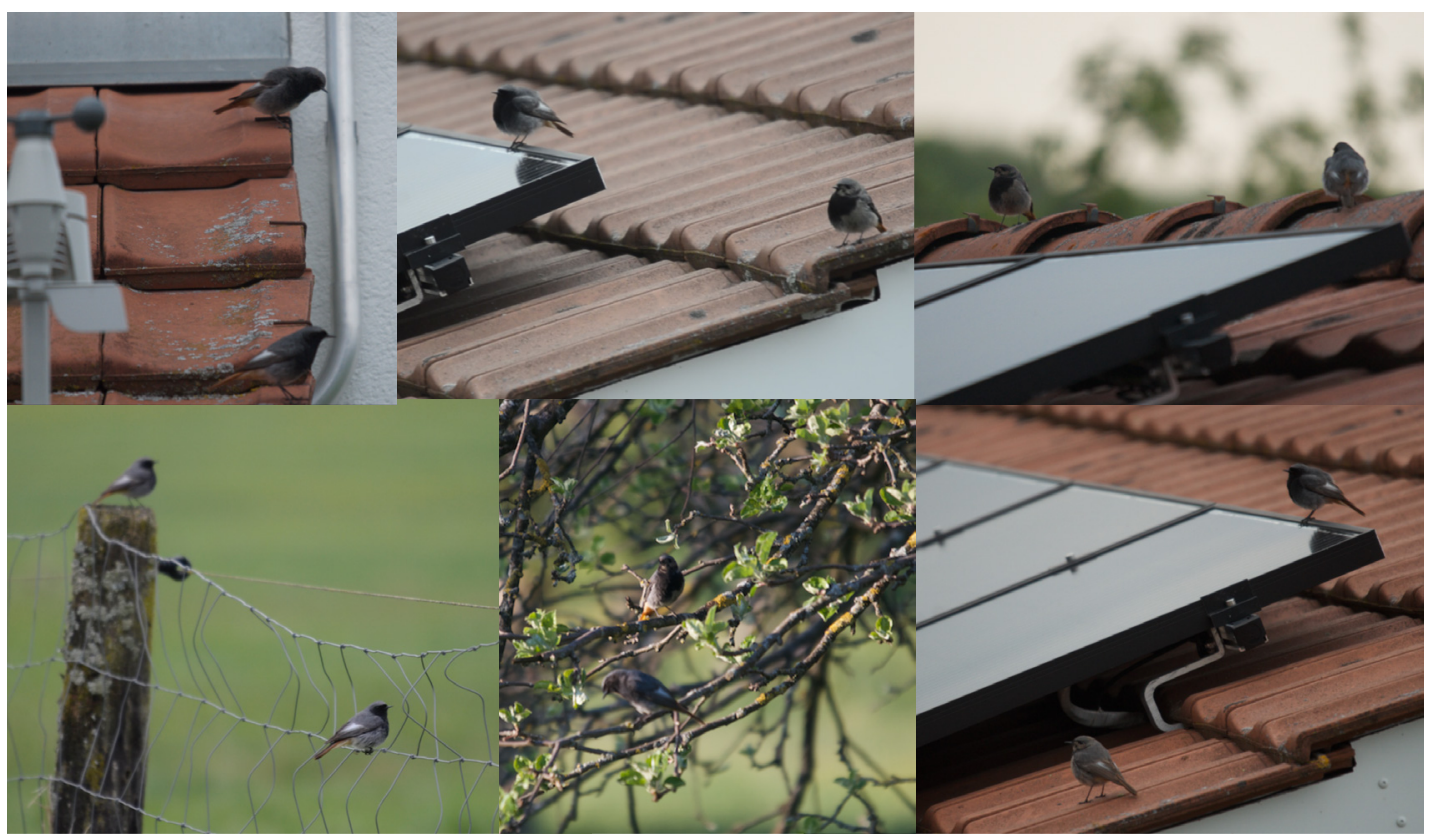

FIGURE 2. The supposed bilateral gynandromorph Black Redstart Phoenicurus ochruros with its partner, a typical adult male Black Redstart. All pictures from April 2019.

- Den förmodat bilaterala gynandromorfa svarta rödstjärten Phoenicurus ochrurus med sin partner, en typisk adult hanne av svart rödstjärt. Alla bilder från april 2019.

female and successfully raised young (Weggler 2005). Given these observations, Gill's (2007) statement that "nothing is known about the breeding activities of such birds" is no longer true, but there are still very few documented observations of breeding activities with gynandromorph birds involved and each additional case may substantially increase our knowledge. In this sense, it is noteworthy that the gynandromorph bird treated in the present article was paired to a male. In two of the three cited records above, the partner was a female (Weggler 2005, Bohlen 2006). Brenner et al. (2019) observed two typical adult males associating with the gynandromorph at a few occasions, but it remained unclear whether this gynandromorph was really paired to one of these males.

The process underlying gynandromorphism is not completely understood and there may be multiple causes (Graves et al. 1996). According to Gill (2007), subsequent to an aberration in the first (mitotic) division of the fertilized ovum, half of a previously female (= heterogametic) bird embryo could lose the W sex chromosome typical of females, with only the $\mathrm{Z}$ sex chromosome remaining. Zhao et al. (2010) studied gynandromorphs of domestic chicken Gallus gallus that probably resulted from an error in oogenesis in the mother of the gynandromorph, resulting into two nuclei in the fertilized ovum. Some cells had ZW sex chromosomes and other cells had ZZ sex chromosomes. Similarly, the right half of the brain was genetically male and the left half genetically female in a captive bred Zebra Finch Taeniopygia guttata (Agate et al. 2003). Dissection of gynandromorph birds showed that they had an ovary on one and a testis on the other side (e.g. Da Costa et al. 2009, Zao et al. 2010, Jones \& Bartlett 2017). Nothing is known about the organs or cellular identity of the bird described in the present article. However, the bird showed behaviour typically referred to males as well as to females, which could be explained by the presence and, subsequently, hormonal activity of female and male cells and organs, although one has to account that same-sex behaviour (comprising courtship, sexual, pair-bonding, and parental activities) has been documented in over 450 species of animals worldwide (Bagemihl 1999). 


\section{Acknowledgements}

I would like to thank Stephen J Brenner, Brian D Peer, Bernd Nicolai, Martin Weggler, Aurélien Martinez, and Céline Martinez for helpful discussions and for sharing their opinion on the bird. Valentin Moser, Reino Andersson and Brian D Peer gave valuable comments that helped to substantially improve the article and Christian Marti (Swiss Ornithological Institute) provided some of the cited references.

\section{References}

Agate RJ, Grisham W, Wade J, Mann S, Wingfield J, Schanen C, Palotie A \& Arnold AP. 2003. Neural, not gonadal, origin of brain sex differences in a gynandromorphic finch. Proceedings of the National Academy of Sciences USA 10o: 4873-4878. https://doi. org/10.1073/pnas.0636925100

Bagemihl B. 1999. Biological Exuberance: Animal Homosexuality and Natural Diversity. St. Martin's Press, New York City, NY, USA.

Bohlen HD. 2006. Illinois sightings of bilateral gynandromorphism in birds. Living Museum 68: 15-16.

Brenner SJ, DaRugna OA \& McWilliams SR. 2019. Observations of certain breeding behaviors in a bilateral gynandromorph Eastern Towhee (Pipilo erythrophthalmus). Wilson Journal of Ornithology 131: 625-628. https://doi.org/10.1676/18-179

Cadbury JWI. 1973. A gynandromorphic Evening Grosbeak in Burlington County, N.J. Cassinia 54: 15-17.
DaCosta JM, Spellman GM \& Klicka J. 2007. Bilateral gynandromorphy in a White-ruffed Manakin (Corapipo altera). Wilson Journal of Ornithology 119: 289-291. https://doi.org/10.1676/06-093.1

Gill FB. 2007. Ornithology. Third Edition. WH Freeman and Co, New York, NY, USA.

Graves GR, Patten MA \& Dunn JL. 1996. Comments on a probable gynandromorphic Black-Throated Blue Warbler. Wilson Bulletin 108: $178-180$.

Jones AW \& Bartlett HT. 2017. A Bilateral Gynandromorph Northern Cardinal from South Bass Island. Ohio Biological Survey Notes 7: $14-16$.

Kumerloeve H. 1954. On gynandromorphism in birds. Emu 54: 71-72. Martinez N, Nicolai B \& van der Spek V. 2019. Redstart hybrids in Europe and North Africa. British Birds 112: 190-201.

Nicolai B, Schmidt C \& Schmidt F-U. 1996. Gefiedermerkmale, Maße und Alterskennzeichen des Hausrotschwanzes Phoenicurus ochruros. Limicola 10: 1-41.

Patten MA. 1993. A probable bilateral gynandromorphic Black-Throated Blue Warbler. Wilson Bulletin 105: 695-698.

Peer BD \& Motz RW. 2014. Observations of a bilateral gynandromorph Northern Cardinal (Cardinalis cardinalis). Wilson Journal of Ornithology 126: 778-781. https://doi.org/10.1676/14-025.1

Weggler M. 2005. Sexualverhalten und Fortpflanzungsfähigkeit eines wahrscheinlich gynandromorphen Hausrotschwanzes Phoenicurus ochruros. Ornithologische Beobachter 102: 145-152.

Zhao D, McBride D, Nandi S, McQueen HA, McGrew MJ, Hocking PM, Lewis PD, Sang HM \& Clinton M. 2010. Somatic sex identity is cell autonomous in the chicken. Nature 464: 237-243. https://doi. org/10.1038/natureo 8852

\section{Svensk sammanfattning}

I denna artikel dokumenterar jag upprepade observationer av en förmodat bilateral gynandromorf svart rödstjärt Phoenicurus ochruros i Rodersdorf, Schweiz. Gynandromorfi definieras som en individ som uppvisar en kombination av hanliga och honliga karaktärer. Hos fåglar och vissa andra djurgrupper kan detta ovanliga fenomen utryckas bilateralt, där ena halvan av individen ser ut som en hona och andra halvan ser ut som en hanne. Gynandromorfi hos fåglar dokumenterades redan på artonhundratalet, och har observerats hos många olika familjer och arter.

I slutet av mars 2019 etablerade ett par av svart rödstjärt ett revir i ett villaområde i Rodersdorf, nordvästra Schweiz ( $47^{\circ} 29^{\prime} 00.3^{\prime \prime N} 7^{\circ} 27^{\prime} 21.8^{\prime \prime} \mathrm{E}$ ). Min första observation av den avvikande fågeln var den 31 mars, och det var tydligt att det inte rörde sig om någon normal hona (se beskrivning av fågelns utseende nedan, figur 1). Under resten av häckningssäsongen observerade jag den avvikande individen vid 27 tillfällen fram till 14 september (se appendix 1). Fågeln observerades i par med en normal adult hanne (i minst sitt tredje kalenderår, $3 \mathrm{~K}+$ ) av samma art. Under april, maj och juni sågs dessa två fåglar nästan enbart tillsammans, utan att någon aggressiv interaktion mellan dem kunde observeras. Efter den 28 juli sågs enbart den gynandromorfa individen $i$ området.

De två fåglarna i paret rörde sig regelbundet tillsammans i reviret under födosök, och sågs ofta sitta tysta nära varandra under vila (se figur 2 och video $\mathrm{i}$ länk: https://www.youtube.com/watch?v=ANBeyp4izOM). Den 13 april observerades att paret gemensamt attackerade och jagade iväg en inkräktare av samma art 
från reviret. Hannen i paret uppvisade vanlig sång och häckningsbeteende från och med slutet av mars. Den gynandromorfa individen hördes sjunga kort för första gången den 13 april, och under maj och juni sjöng även denna individ regelbundet (se nedan för beskrivning av sången). När en av de två individerna i paret sjöng, satt den andra ibland tyst ett par meter bort. Jag observerade aldrig några försök till bobygge, häckning eller parning.

Den högra kroppshalvan av den avvikande fågeln såg ut som en typisk adult hanne $(3 \mathrm{~K}+)$, med svartgrå dräkt och en stor vit vingpanel och rödaktig stjärt, gump och stjärttäckare (se figur 1). Vid noggranna studier av fotografier har jag inte kunna hitta några bruna fjädrar eller andra honliga karaktärer på denna sida. Den vänstra kroppshalvan var mycket mer variabel, med ett övervägande honligt utseende och matt brungrå färg. Men här fanns även tydliga inslag av hanliga karaktärer, speciellt på överdelen av bröstet och vissa helsvarta partier på huvudet. På ryggen observerades en blandning av gråbruna (honliga) och helgrå (hanliga) fjädrar. Även den vänstra vingen uppvisade en blandning av honliga och hanliga fjädertyper. Den svarta rödstjärten genomgår en komplett ruggning efter häckningen i juli och augusti. Efter att den gynandromorfa individen genomgått denna ruggning var samtliga nya fjädrar av samma typ som före ruggningen (jämför den övre och undre raden av foton in figur 1).

Den gynandromorfa individen sjöng som en normal svart rödstjärt. Sången startade med några visslande toner följda av en kort paus och de arttypiska gnissliga ljuden, och strofen avslutades med ytterligare några visslingar. Precis som hos vanliga svarta rödstjärtar var vissa strofer icke-kompletta. Stroferna varade i ca 4 sekunder, som hos vanliga hanar av arten. Inspelning- ar av sången finns via följande länkar: https://www. xeno-canto.org/471015 och https://www.xeno-canto. org $/ 471014$.

Vid en första anblick hade man kunnat tro att den förmodat gynandromorfa individen skulle vara en ung hanne i sitt andra kalenderår $(2 \mathrm{~K})$ med delvis fördröjd postjuvenil ruggning, eftersom den juvenila fjäderdräkten är mycket lik honans dräkt. Men arm- och handpennor hos svart rödstjärt uppvisar vita konturer först efter den första sommarens kompletta ruggning. Individen i fråga kunde därför åldersbestämmas till $3 \mathrm{~K}+$. De fjädrar som varit av honligt utseende under vår och försommar behöll även samma utseende efter sommarens kompletta ruggning.

Så vitt jag vet finns enbart en tidigare dokumenterad observation av en gynandromorf svart rödstjärt. Mina observationer som beskrivs här är också ovanliga i och med att jag dokumenterat individen under hela häckningssäsongen och både före och efter komplett ruggning. Jag har också dokumenterat sång och revirbeteende hos individen i fråga. I de tidigare dokumenterade fall av vilda gynandromorfa fåglar (exempelvis hos röd kardinal Cardinalis cardinalis) där man observerat parbildning, har den gynandromorfa individen i stället bildat par (och ibland även lyckats med häckning) med en hona av samma art.

Mekanismen bakom gynandromorfi hos fåglar är inte helt kartlagd. Troligen beror detta fenomen oftast på ett fel i celldelningen väldigt tidigt i embryoutvecklingen, där hälften av cellerna förlorar en av könskromosomerna. Alternativt kan det vara så att två befruktade äggceller slås ihop och sedan bidrar i lika grad till embryot. Dissektioner av gynandromorfa fåglar har visat att dessa har testiklar i ena kroppshalvan och äggstockar i den andra halvan.

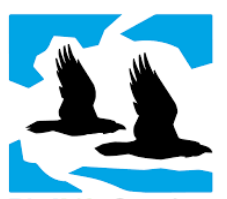

BirdLife Sverige

Ornis Svecica (ISSN 2003-2633) is an open access, peer-reviewed scientific journal published in English and Swedish by BirdLife Sweden. It covers all aspects of ornithology, and welcomes contributions from scientists as well as non-professional ornithologists. Accepted articles are published at no charge to the authors. Read papers or make a submission at os.birdlife.se.

Ornis Svecica (ISSN 2003-2633) är en fritt tillgänglig granskad vetenskaplig tidskrift som ges ut på svenska och engelska av BirdLife Sverige. Den täcker ornitologins alla områden och välkomnar bidrag från såväl forskare som icke-professionella ornitologer. Accepterade uppsatser publiceras utan kostnad för författarna. Läs uppsatser eller skicka in ditt bidrag på os.birdlife.se. 


\section{Appendix 1. Observation dates of the supposed gynandromorph with information on interactions with the supposed mate and song activity}

\begin{tabular}{|c|c|c|c|c|}
\hline $\begin{array}{l}\text { Observation date } \\
\text { (YYYY-MM-DD) } \\
\text { Observationsdatum } \\
(A \AA \AA A-M M-D D)\end{array}$ & $\begin{array}{l}\text { Together with normal } \\
\text { Black Redstart male } \\
\text { Tillsammans med normal } \\
\text { svart rödstjärtshanne }\end{array}$ & $\begin{array}{l}\text { Song } \\
\text { Sång }\end{array}$ & Comments Kommentarer & $\begin{array}{l}\text { Photos } \\
\text { Foton }\end{array}$ \\
\hline 2019-03-31 & yes & no & & yes \\
\hline 2019-04-05 & yes & no & video & yes \\
\hline 2019-04-06 & yes & no & & yes \\
\hline 2019-04-07 & yes & no & & yes \\
\hline 2019-04-10 & yes & no & & no \\
\hline 2019-04-13 & yes & yes & song: only briefly & yes \\
\hline 2019-04-14 & yes & no & & yes \\
\hline 2019-04-19 & yes & yes & both birds sing simultaneously & no \\
\hline 2019-04-20 & yes & no & & no \\
\hline 2019-04-21 & yes & no & & no \\
\hline 2019-04-27 & yes & yes & both birds sing simultaneously & yes \\
\hline 2019-04-28 & yes & not noted & & no \\
\hline 2019-04-29 & yes & not noted & video & yes \\
\hline 2019-05-01 & yes & not noted & & yes \\
\hline 2019-05-06 & yes & yes & song recordings 1 and 2 & yes \\
\hline 2019-05-16 & yes & yes & & no \\
\hline $2019-05-25$ & yes & not noted & & no \\
\hline 2019-06-13 & yes & yes & & no \\
\hline 2019-06-17 & yes & yes & & yes \\
\hline 2019-06-21 & yes, but at times alone & yes & & no \\
\hline $2019-06-28$ & yes, but at times alone & yes & & yes \\
\hline 2019-07-24 & not noted & not noted & & no \\
\hline 2019-07-26 & not noted & not noted & & no \\
\hline 2019-07-28 & yes, but at times alone & not noted & & yes \\
\hline 2019-08-11 & not noted & yes & & yes \\
\hline 2019-09-05 & no & no & & no \\
\hline 2019-09-14 & no & no & & yes \\
\hline
\end{tabular}

